Scientific paper

\title{
Synthesis, Crystal Structure and Biological Activity Screening of Novel $N$-( $\alpha$-Bromoacyl)- $\alpha$-amino Esters Containing Valyl Moiety
}

\author{
Denista Yancheva, ${ }^{1}$ Emiliya Cherneva, ${ }^{2}$ Markus Quick, ${ }^{3}$ Bozhanka Mikhova, ${ }^{1}$ \\ Boris Shivachev, ${ }^{4}$ Rosisa Nikolova, ${ }^{4}$ Aleksandra Djordjevic, ${ }^{5}$ Monika Untergehrer, ${ }^{3}$ \\ Guido Jürgenliemk, ${ }^{3}$ Birgit Kraus ${ }^{3, *}$ and Andrija Smelcerovic ${ }^{6, *}$ \\ ${ }^{1}$ Institute of Organic Chemistry with Centre of Phytochemistry, Bulgarian Academy of Sciences, Acad. G. Bonchev \\ Str., build. 9, 1113 Sofia, Bulgaria \\ ${ }^{2}$ Department of Chemistry, Faculty of Pharmacy, Medical University of Sofia, 2 Dunav Str., 1000 Sofia, Bulgaria \\ ${ }^{3}$ Institute of Pharmacy, Pharmaceutical Biology, University of Regensburg, Universitätstraße 31, 93053 Regensburg, Germany \\ ${ }^{4}$ Institute of Mineralogy and Crystallography »Acad. Ivan Kostov«, Bulgarian Academy of Sciences, Acad G. Bonchev \\ Str. build. 107, 1113 Sofia, Bulgaria \\ ${ }^{5}$ Department of Chemistry, Faculty of Science and Mathematics, University of Niš, 18000 Niš, Serbia \\ ${ }^{6}$ Department of Chemistry, Faculty of Medicine, University of Niš, Bulevar Dr Zorana Djindjića 81,18000 Niš, Serbia \\ * Corresponding author: E-mail: birgit1.kraus@chemie.uni-regensburg.de; a.smelcerovic@yahoo.com \\ Tel.: +49941 9434494; Fax: +49941 9434990, Tel.: +381 184570029 ; Fax: +381 184238770.
}

Received: 08-02-2015

\begin{abstract}
Three novel $N$-( $\alpha$-bromoacyl)- $\alpha$-amino esters: methyl 2-(2-bromo-3-methylbutanamido)pentanoate (1), methyl 2-(2bromo-3-methylbutanamido)-2-phenylacetate (2) and methyl 2-(2-bromo-3-methylbutanamido)-3-phenylpropanoate (3) were synthesized. Single crystal X-ray diffraction data are reported for compounds $\mathbf{1}$ and $\mathbf{2}$. The cytotoxicity, antiinflammatory and antibacterial activity of compounds 1-3 were investigated. Additionally, the physico-chemical properties of studied compounds were calculated and an in silico toxicological study of compounds 1-3 was performed. The low level of cytotoxicity and absence of antibacterial and anti-inflammatory activity of $\mathbf{1}-\mathbf{3}$ in tested concentrations might be a beneficial prerequisite for their incorporation in prodrugs.
\end{abstract}

Keyword: $N$-( $\alpha$-bromoacyl)- $\alpha$-amino esters; X-ray structure; cytotoxicity; anti-inflammatory activity; antibacterial activity.

\section{Introduction}

Searching for new potent drugs with enhanced physiological performance, many studies have been focused on the design of dipeptide-based prodrugs of known medications. The synthesis of dipeptide esters of acyclovir (2-amino-9-(2-hydroxyethoxymethyl)-3H-purin-6one) (Fig. 1) and structurally related antiherpetic drugs gancyclovir (2-amino-9-(1,3-dihydroxypropan-2-yloxymethyl)-3H-purin-6-one) and saquinavir $((2 S)-N-[(2 S$,
$3 R)$ - 4 - [( $3 S, 4$ a $S, 8$ a $S)$ - 3 - (tert-buty lcarba moyl) 3,4,4a,5,6,7,8,8a-octahydro- $1 H$-isoquinolin-2-yl]-3-hydroxy-1-phenylbutan-2-yl]-2-(quinoline-2-carbonylamino)butanediamide), lead to the discovery of new analogues with higher water-solubility at physiological $\mathrm{pH}$ and improved membrane permeability. ${ }^{1-5}$ The same strategy was also successfully applied in the development of new prodrugs of floxuridine (5-fluoro-1-[(2R,4S,5R)-4-hydroxy-5-(hydroxymethyl)oxolan-2-yl]pyrimidine-2,4dione) and azidothymidine (1-[(2R,4S,5S)-4-azido-5- 
<smiles>CC(C)C(N)C(=O)NC(C(=O)OCCOCn1cnc2c(=O)[nH]c(N)nc21)C(C)C</smiles>

Dipeptide analogue of acyclovir (Val-Val-ACV)

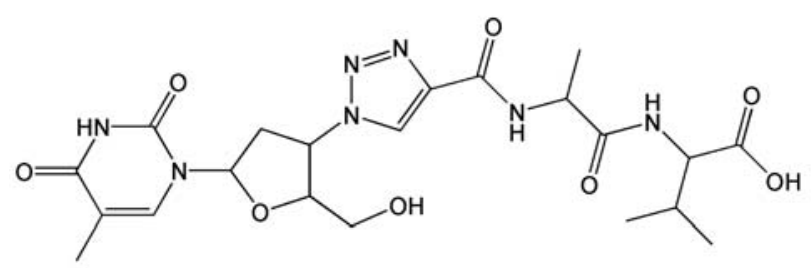

Dipeptide analogue of azidothymidine (Val-Ala-AZT)

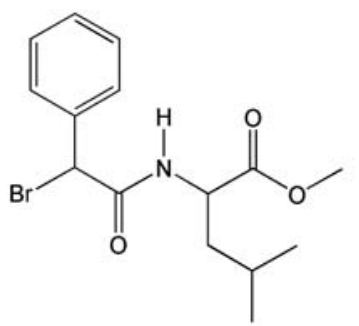

$\mathrm{N}$-( $\alpha$-haloacyl)- $\alpha$-amino ester:

Br-Phg-Leu-OMe

Figure 1. Dipeptide analogues of acyclovir and azidothymidine, cyclodidepsipeptides and $N$-( $\alpha$-haloacyl)- $\alpha$-amino esters.

(hydroxymethyl)oxolan-2-yl]-5-methylpyrimidine-2,4dione) (Fig. 1) for anticancer therapy. ${ }^{6-9}$

Dipeptides represent attractive pro-moieties for generating dipeptide prodrugs also of other drugs containing hydroxyl- ${ }^{10-12}$ thiol- ${ }^{4}$ and amino groups. ${ }^{13-15}$ Variation of the dipeptide carrier structure allows fine adjustment of the lipophilicity, prodrug stability and pharmacological activity.

In different prodrug design strategies, drug functional groups are coupled to dipeptide moiety as esters via Cterminal carboxylic group ${ }^{1-4,9,12,15}$ and side-chain hydroxy residues,${ }^{11}$ or amides via $N$-terminal amine group. ${ }^{8}$ The peptide moiety of a prodrug could be further modified by nucleophilic substitution if an $\alpha$-haloacyl atom is introduced at the $N$-terminal end of the dipeptide. ${ }^{16,17} \mathrm{~N}-(\alpha$ Haloacyl)- $\alpha$-amino esters (Fig. 1) have been shown to react readily with various amine nucleophiles in the stereoselective preparation of $\mathrm{N}$-terminal functionalized dipeptide analogues. ${ }^{18,19}$

$N$-( $\alpha$-Haloacyl)- $\alpha$-amino esters are linear precursors in the synthesis of cyclodepsipeptides which are known to exhibit diverse biological effects, such as antimicrobial $^{20-22}$ and immunomodulatory ${ }^{20,21,23}$ activity. Moreover, cyclodidepsipeptides exhibit inhibitory activity towards xanthine oxidase, ${ }^{24}$ acyl-CoA:cholesterol acyltransfera$\mathrm{se}^{25}$ and $\alpha$-glucosidase $\mathrm{e}^{26-28}$ as well as platelet aggregation inhibition. ${ }^{29}$ For this reason, it was thought worthwhile to synthesize and study the pharmacological activities of three $N$-( $\alpha$-bromoacyl)- $\alpha$-amino esters. Valine (Val) was selected as the $N$-terminal amino acid for the preparation of $N$-( $\alpha$-bromoacyl)- $\alpha$-amino esters based on our previous studies on the biological activities of valine-containing cyclic didepsipeptides. ${ }^{20-22,24,30}$ At the C-terminal end of the dipeptide, three amino esters with aliphatic (norvaline) and aromatic (phenylglycine and phenylalanine) side chains were positioned in order to exhibit different physico-chemical properties. Cytotoxicity, ${ }^{31-33}$ anti-inflammatory $^{34}$ and antibacterial ${ }^{35}$ activity are some of the most commonly investigated biological activities of new compounds and therefore one of the aims of the present study was to investigate the above-mentioned activities of three synthesized $N$-( $\alpha$-bromoacyl)- $\alpha$-amino esters. Additionally, the physico-chemical properties of studied compounds were calculated using Molinspiration tool ${ }^{36}$ and an in silico toxicological study was performed using the OSIRIS Property Explorer. ${ }^{37}$

\section{Experimental}

\section{1. Chemistry}

\section{1. 1. Materials}

L-Phenylglycine methyl ester hydrochloride and L-phenylalanine methyl ester hydrochloride were purchased from Bachem AG. Dichloromethane and triethylamine were purchased from Sigma-Aldrich. D-Norvaline methyl ester hydrochloride was prepared from D-norvaline (Bachem AG) by treatment with thionylchloride and methanol. The $(R, S)$-2-bromo-3-methylbutanoyl chloride was obtained using earlier reported experimental protocols. ${ }^{30,38}$

\section{1. 2. IR Spectra Measurements}

The FT-IR spectra of $\mathbf{1}-\mathbf{3}$ were measured in solid state (in $\mathrm{KBr}$ ) on a Brucker Tensor 27 FT spectrometer at a resolution of $2 \mathrm{~cm}^{-1}$ and 64 scans. Commercially available spectral quality $\mathrm{CDCl}_{3}$ and DMSO- $d_{6}$ were employed as solvents. The following sample cells were used: $0.6 \mathrm{mM} \mathrm{NaCl}$ for $\mathrm{CDCl}_{3}(0.1 \mathrm{M})$ solution; and $0.129 \mathrm{mM}$ $\mathrm{CaF}_{2}$ for DMSO- $d_{6}(0.1 \mathrm{M})$ solution.

\section{1. 3. NMR Spectra Measurements}

The NMR spectra were recorded on a Bruker DRX250 spectrometer in solvent DMSO- $d_{6}$ using TMS as 
internal standard. The structures of the investigated compounds were elucidated with the help of $1 \mathrm{D}$ and 2D (COSY, HMQC, HMBC) spectra. Standard Bruker pulse sequences and software were used to record and process the spectra.

\section{1. 4. Synthesis of Noncyclic Dipeptides 1-3}

The synthetic route for the preparation of $N-(\alpha-b r o-$ moacyl)- $\alpha$-amino esters $\mathbf{1 - 3}$ is illustrated in Scheme 1.

General procedure: Amino acid methyl ester hydrochloride $(2 \mathrm{mmol})$ was dissolved in $25 \mathrm{~mL}$ dry dichloromethane and $6 \mathrm{mmol}$ of triethylamine was added. The solution was cooled in ice bath, and $3 \mathrm{mmol}$ of $(R, S)$ 2-bromo-acyl chloride was added dropwise. The mixture was stirred for $2 \mathrm{~h}$, and then the temperature was allowed to rise to room temperature. The reaction mixture was washed by $0.5 \mathrm{M} \mathrm{HCl}, 10 \% \mathrm{NaHCO}_{3}$ and brine. The combined organic layers were dried over sodium sulfate and the solvent was removed under reduced pressure.

\section{Methyl 2-(2-Bromo-3-methylbutanamido)-pentanoate} (1)

After multiple recrystallization from methanol/water (4:1) mixture, crystals as coloreless needles were obtained. $\mathrm{C}_{11} \mathrm{H}_{20} \mathrm{BrNO}_{3}(M=294.19)$; yield 65\%; m.p. 97-98 ${ }^{\circ} \mathrm{C}$; MS: $\mathrm{m} / z$ 293, $295\left(\mathrm{M}^{+}\right)$; IR (KBr): $\mathrm{cm}^{-1} 3296$, 3086, 2962, 2933, 2874, 1744, 1653, 1562, 1555, 1467, $1437,1382,1347,1325,1303,1273,1235,1219,1196$, 1149, 1111, 995, 938; ${ }^{1} \mathrm{H}$ NMR (250 $\left.\mathrm{MHz}, \mathrm{CDCl}_{3}\right): \delta$ (ppm) $6.89\left(1 \mathrm{H}, \mathrm{d}, J=7.0 \mathrm{~Hz}, \mathrm{NH}_{\text {minor }}\right), 6.86(1 \mathrm{H}, \mathrm{d}, J=$ $\left.7.5 \mathrm{~Hz}, \mathrm{NH}_{\text {major }}\right), 4.59$ (2H, m, H-3 major, $\left.\mathrm{H}-3_{\text {minor }}\right), 4.33$ $\left(1 \mathrm{H}, \mathrm{d}, J=4.5 \mathrm{~Hz}, \mathrm{H}-6_{\text {major }}\right), 4.32(1 \mathrm{H}, \mathrm{d}, J=4.5 \mathrm{~Hz}$, $\left.\mathrm{H}-6_{\text {minor }}\right), 3.78\left(3 \mathrm{H}, \mathrm{s}, \mathrm{OCH}_{3}-10_{\text {minor }}\right), 3.77(3 \mathrm{H}, \mathrm{s}$, $\left.\mathrm{OCH}_{3}-10_{\text {major }}\right), 2.40\left(2 \mathrm{H}, \mathrm{m}, \mathrm{H}-11_{\text {major }}, \mathrm{H}-11_{\text {minor }}\right), 1.74(4 \mathrm{H}$, $\left.\mathrm{m}, \mathrm{CH}_{2}-14_{\text {major }}, \mathrm{CH}_{2}-14_{\text {minor }}\right), 1.39\left(4 \mathrm{H}, \mathrm{m}, \mathrm{CH}_{2}-15_{\text {major }}\right.$, $\left.\mathrm{CH}_{2}-15_{\text {minor }}\right), 1.09\left(3 \mathrm{H}, \mathrm{d}, J=6.5 \mathrm{~Hz}, \mathrm{CH}_{3 \text { major }}\right), 1.08(3 \mathrm{H}, \mathrm{d}$, $\left.J=6.5 \mathrm{~Hz}, \mathrm{CH}_{3 \text { minor }}\right), 1.03\left(3 \mathrm{H}, \mathrm{d}, J=6.5 \mathrm{~Hz}, \mathrm{CH}_{3 \text { major }}\right)$, $1.01\left(3 \mathrm{H}, \mathrm{d}, J=6.5 \mathrm{~Hz}, \mathrm{CH}_{3 \text { minor }}\right), 0.96(3 \mathrm{H}, \mathrm{t}, J=6.5 \mathrm{~Hz}$, $\left.\mathrm{CH}_{3}-16_{\text {major }}\right), 0.95\left(3 \mathrm{H}, \mathrm{t}, J=6.5 \mathrm{~Hz}, \mathrm{CH}_{3}-16_{\text {minor }}\right)$. Approximately 1.3:1.0 mixture of two diastereomers as determined from the integrated intensity of the signals. ${ }^{13} \mathrm{C}$ NMR $\left(62.5 \mathrm{MHz} \mathrm{CDCl}_{3}\right): \delta(\mathrm{ppm}) 172.5\left(\mathrm{C}-2_{\text {major }}\right), 172.4(\mathrm{C}-$ $\left.2_{\text {minor }}\right), 168.0$ (C-5 $\left.{ }_{\text {major }}\right), 167.9$ (C-5 $\left.5_{\text {minor }}\right), 61.1\left(\mathrm{C}-6_{\text {major }}\right)$, $61.0\left(\mathrm{C}-6_{\text {minor }}\right), 52.63\left(\mathrm{C}-3_{\text {minor }}\right), 52.60\left(\mathrm{C}-3_{\text {major }}\right), 52.43$ $\left(\mathrm{C}-10_{\text {minor }}\right), 52.40\left(\mathrm{C}-10_{\text {major }}\right), 34.3\left(\mathrm{C}-14_{\text {minor }}\right), 34.1$ (C$\left.14_{\text {major }}\right), 32.6$ (C-11 $\left.1_{\text {major }}\right), 32.3$ (C-11 $\left.1_{\text {minor }}\right), 20.9$ (2C, $\left.\mathrm{CH}_{3 \text { major }}, \mathrm{CH}_{3 \text { minor }}\right), 18.6$ (C-15 major $), 18.52$ (C-15 minor $)$, $18.46\left(\mathrm{CH}_{3 \text { minor }}\right), 18.3\left(\mathrm{CH}_{3 \text { major }}\right), 13.6\left(2 \mathrm{C}, \mathrm{C}-16_{\text {major }}\right.$, $\mathrm{C}-$ $\left.16_{\text {minor }}\right)$.

\section{Methyl 2-(2-Bromo-3-methylbutanamido)-2-phenyla- cetate (2)}

After multiple recrystallization from methanol/water (4:1) mixture, crystals as light yellow needles. $\mathrm{C}_{14} \mathrm{H}_{18} \mathrm{BrNO}_{3}(M=328.20)$; yield 61\%; m.p. $121-122^{\circ} \mathrm{C}$; MS: $m / z$ 327, $329\left(\mathrm{M}^{+}\right)$; IR (KBr): $\mathrm{cm}^{-1} 3306,3089,3066$, 3035, 2964, 2927, 2873, 2851, 1737, 1655, 1603, 1587, 1546, 1496, 1468, 1454, 1433, 1380, 1350, 1320, 1302, $1275,1219,1196,1182,1129,1099,1072,1032,989,941$, 778, 746, 723, 694, 670, 637, 615; ${ }^{1} \mathrm{H}$ NMR (250 MHz, DMSO- $\left.d_{6}\right): \delta(\mathrm{ppm}) 9.12\left(1 \mathrm{H}, \mathrm{d}, J=7.0 \mathrm{~Hz}, \mathrm{NH}_{\text {major }}\right), 9.06$ $\left(1 \mathrm{H}, \mathrm{d}, J=7.0 \mathrm{~Hz}, \mathrm{NH}_{\text {minor }}\right), 7.4-7.2(10 \mathrm{H}, \mathrm{m}, \mathrm{Ph}), 5.46$ $\left(1 \mathrm{H}, J=7.0 \mathrm{~Hz}, \mathrm{H}-3_{\text {major }}\right), 5.37\left(1 \mathrm{H}, J=7.0, \mathrm{H}-3_{\text {minor }}\right)$, $4.35\left(2 \mathrm{H}, \mathrm{d}, J=9.0 \mathrm{~Hz}, \mathrm{H}-6_{\text {major }}, \mathrm{H}-6_{\text {minor }}\right), 3.64$ (3H, s, $\left.\mathrm{OCH}_{3}-10_{\text {major }}\right), 3.62\left(3 \mathrm{H}, \mathrm{s}, \mathrm{OCH}_{3}-10_{\text {minor }}\right), 2.01(2 \mathrm{H}, \mathrm{m}$, $\left.\mathrm{H}-11_{\text {major }}, \mathrm{H}-11_{\text {minor }}\right), 1.06\left(3 \mathrm{H}, \mathrm{d}, J=6.5 \mathrm{~Hz}, \mathrm{CH}_{3 \text { major }}\right)$, $1.01\left(3 \mathrm{H}, \mathrm{d}, J=7.0 \mathrm{~Hz}, \mathrm{CH}_{3 \text { minor }}\right), 0.98(3 \mathrm{H}, \mathrm{d}, J=7.0 \mathrm{~Hz}$, $\left.\mathrm{CH}_{3 \text { minor }}\right), 0.84\left(3 \mathrm{H}, \mathrm{d}, J=6.5 \mathrm{~Hz}, \mathrm{CH}_{3 \text { major }}\right)$. Mixture of two diastereomers $2: 1$ as determined from the integrated intensity of the signals. ${ }^{13} \mathrm{C}$ NMR $\left(62.5 \mathrm{MHz}, \mathrm{DMSO}-d_{6}\right)$ : $\delta(\mathrm{ppm}) 170.7$ (C-2 minor $), 170.6\left(\mathrm{C}-2_{\text {major }}\right), 168.4\left(\mathrm{C}-5_{\text {minor }}\right)$, 168.1 (C-5 major $), 136.1$ (C-i $\left.i_{\text {major }}\right), 135.4\left(\mathrm{C}-i_{\text {minor }}\right), 128.6$ $\left(\mathrm{C}-m_{\text {minor }}\right), 128.4 \quad\left(\mathrm{C}-m_{\text {major }}\right), 127.9$ (C-o $\left.o_{\text {minor }}\right), 127.6$ $\left(\mathrm{C}-o_{\text {major }}\right), 128.6\left(\mathrm{C}-p_{\text {minor }}\right), 128.4\left(\mathrm{C}-p_{\text {major }}\right), 56.7\left(\mathrm{C}-3_{\text {mi- }}\right.$ nor $), 56.63\left(\mathrm{C}-6_{\text {major }}\right), 56.57\left(\mathrm{C}-6_{\text {minor }}\right), 56.3\left(\mathrm{C}-3_{\text {major }}\right), 52.4$ (C-10 major $), 52.3$ (C-10 minor $), 32.1$ (C-11 $\left.1_{\text {major }}, \mathrm{C}-11_{\text {minor }}\right)$, $20.4\left(\mathrm{CH}_{3 \text { minor }}\right), 20.3\left(\mathrm{CH}_{3 \text { major }}\right), 19.4\left(2 \mathrm{C}, \mathrm{CH}_{3 \text { major }}\right.$, $\mathrm{CH}_{3 \text { minor }}$ ).

\section{Methyl 2-(2-Bromo-3-methylbutanamido)-3-phenyl- propanoate (3)}

After multiple recrystallization from methanol/water (4:1) mixture, crystals as light yellow need-<smiles>[R]C(N)C(=O)OC</smiles>

$$
\begin{aligned}
& \mathrm{R}^{1}=-\mathrm{CH}_{2} \mathrm{CH}_{2} \mathrm{CH}_{3} \\
& \mathrm{R}^{1}=-\mathrm{C}_{6} \mathrm{H}_{5} \\
& \mathrm{R}^{1}=-\mathrm{CH}_{2} \mathrm{C}_{6} \mathrm{H}_{5}
\end{aligned}
$$<smiles>[R]C(Br)C(=O)N([1H])C([R])C(=O)OC</smiles>

(1) $\mathrm{R}^{1}=-\mathrm{CH}_{2} \mathrm{CH}_{2} \mathrm{CH}_{3} ; \mathrm{R}^{2}=-\mathrm{CH}\left(\mathrm{CH}_{3}\right)_{2}$

(2) $\mathrm{R}^{1}=-\mathrm{C}_{6} \mathrm{H}_{5} ; \mathrm{R}^{2}=-\mathrm{CH}\left(\mathrm{CH}_{3}\right)_{2}$

(3) $\mathrm{R}^{1}=-\mathrm{CH}_{2} \mathrm{C}_{6} \mathrm{H}_{5} ; \mathrm{R}^{2}=-\mathrm{CH}\left(\mathrm{CH}_{3}\right)_{2}$

Scheme 1. Synthesis of $N$-( $\alpha$-bromoacyl)- $\alpha$-amino esters $\mathbf{1 - 3}$. 
les. $\mathrm{C}_{15} \mathrm{H}_{20} \mathrm{BrNO}_{3}(M=342.23)$; yield 67\%; m.p. 94-95 ${ }^{\circ} \mathrm{C}$; MS: $m / z$ 341, $343\left(\mathrm{M}^{+}\right)$; IR (KBr): $\mathrm{cm}^{-1} 3336,3247$, 3077, 3065, 3030, 2971, 2953, 2941, 2873, 1744, 1654, 1604, 1585, 1557,1527, 1496, 1454, 1443, 1436, 1373, $1355,1338,1320,1276,1222,1203,1173,1103,1075$, 1031, 997, 937, 819, 792, 771, 755, 729, 697, 668, 611; ${ }^{1} \mathrm{H}$ NMR (250 MHz, DMSO- $\left.d_{6}\right): \delta(\mathrm{ppm}) 8.70,8.68$ $(2 \mathrm{H}, \mathrm{d}, J=8.0 \mathrm{~Hz}, \mathrm{NH}), 7.2-6.9(10 \mathrm{H}, \mathrm{m}, \mathrm{Ph}), 4.53$, $4.47(2 \mathrm{H}, \mathrm{m}, 2 \mathrm{H}-3), 4.16,4.59(2 \mathrm{H}, \mathrm{d}, J=9.0 \mathrm{~Hz}$, $2 \mathrm{H}-6), 3.63,3.59\left(6 \mathrm{H}, \mathrm{s}, 2 \mathrm{OCH}_{3}-10\right), 3.00,2.91(2 \mathrm{H}$, $\mathrm{m}, 2 \mathrm{H}-14), 2.01,1.94$ (2H, m, 2H-11), 0.99 (3H, d, J = $\left.6.5 \mathrm{~Hz}, \mathrm{CH}_{3}\right), 0.90\left(3 \mathrm{H}, \mathrm{d}, J=7.0 \mathrm{~Hz}, \mathrm{CH}_{3}\right), 0.85(3 \mathrm{H}$, $\left.\mathrm{d}, J=6.5 \mathrm{~Hz}, \mathrm{CH}_{3}\right), 0.67\left(3 \mathrm{H}, \mathrm{d}, J=7.0 \mathrm{~Hz}, \mathrm{CH}_{3}\right)$. Mixture of two diastereomers $1: 1$ as determined from the integrated intensity of the signals. ${ }^{13} \mathrm{C}$ NMR $(62.5$ $\left.\mathrm{MHz}, \mathrm{DMSO}-d_{6}\right): \delta(\mathrm{ppm}) 171.7,171.6$ (2C-2), 168.5, 168.1 (2C-5), 137.1, 136.9 (2C-i), 129.2, 129.1 (2C-m), $128.4,128.3$ (2C-o), 126.7, $126.6(2 \mathrm{C}-p), 57.2,57.0$ (2C-6), 53.8, 53.6 (2C-3), 52.1, 52.0 (2C-10), 36.6, 36.4 (2C-14), 32.1, 31.9 (2C-11), 20.3, 20.2, 19.4, 19.2 $\left(4 \mathrm{CH}_{3}\right)$.

\section{1. 5. Crystallographic Studies}

Crystals of $\mathbf{1}$ and $\mathbf{2}$ were mounted on a glass capillary and all geometric and intensity data were taken from these crystals. Data collection was performed at room temperature on an Agilent Dual Supernova diffractometer with $\mathrm{Cu}-\mathrm{K} \alpha$ radiation $(\lambda=1.54181 \AA)$. Unit cell and subsequent data reduction were performed using Agilent CrysalisPro package. ${ }^{39}$ The structures were solved with SHELXS-97 ${ }^{40}$ and refined using full-matrix least-squares on $F^{2}$ with the SHELXL-97 package. ${ }^{40}$

CCDC No 928665 and 928666 (for 1 and 2) contain the supplementary crystallographic data for this paper. These data can be obtained free of charge from the Cambridge Crystallographic Data Centre via www.ccdc.cam. ac.uk/data_request/cif.

\section{2. Biological Assays}

\section{2. 1. Cells and Cell Culture}

The human cervical adenocarcinoma cell line HeLa was grown under standard cell culture conditions in Minimum Essential Medium (MEM) supplemented with $10 \%$ fetal calf serum (FCS), 2 mM L-glutamine and $1 \%$ nonessential aminoacids (all from Biochrom).

The mouse macrophage cell line RAW 264.7 $7^{41}$ was cultured in RPMI-1640 medium supplemented with $10 \%$ heat-inactivated FCS and $2 \mathrm{mM}$ L-glutamine (all from Biochrom).

The human microvascular endothelial cell line HMEC- $1^{42}$ was grown in endothelial cell growth medium (ECGM) supplemented with 10\% FCS, antibiotics and supplements (all from Provitro).

\section{2. 2. Determination of Cell Viability by MTT Assay}

Cell viability was evaluated by MTT assays as described. ${ }^{43}$ In brief, cells were seeded in 96-well plates at a density of $9 \times 10^{3}$ per well for HeLa cells or $5 \times 10^{3}$ per well for RAW264.7 cells, and cultured for $24 \mathrm{~h}$. Then, cells were incubated for another $24 \mathrm{~h}$ either with medium only, medium supplemented with studied compounds or corresponding solvent (ethanol) concentrations. After treatment, medium was removed, $100 \mu \mathrm{L}$ of MTT solution $(0.4 \mathrm{mg} / \mathrm{mL}$ in medium) were added to each well and cells were incubated for another $3 \mathrm{~h}$ at $37^{\circ} \mathrm{C}$. Subsequently supernatants were removed, $100 \mu \mathrm{L}$ of a $10 \%$ SDS solution were added to each well and formazan was allowed to dissolve overnight. Absorbance was determined at $560 \mathrm{~nm}$ with a multiwell plate photometer (TiterTek).

\section{2. 3. Measurement of Nitrite Production by Griess Assay}

The generation of nitric oxide (NO) by inducible NO-synthase (iNOS) was determined by measuring the accumulation of nitrite $\left(\mathrm{NO}_{2}^{-}\right)$in the cell culture medium using a microplate assay method, based on the Griess reaction and performed as described previously. $^{44}$ Briefly, RAW264.7 cells were seeded in 96-well plates at a density of $8 \times 10^{4}$ cells per well and cultured for $24 \mathrm{~h}$. Subsequently, the cells were treated with lipopolysaccharide (LPS) $(10 \mathrm{ng} / \mathrm{mL}$ in RPMI without phenol red) from $E$. coli serotype 055:B5 (Sigma) in order to induce NO production by iNOS and incubated for another $24 \mathrm{~h}$ either with medium only or medium supplemented with studied compounds or corresponding ethanol concentrations. A volume of $50 \mu \mathrm{L}$ culture supernatant was mixed with $50 \mu \mathrm{L}$ Griess reagent $(1 \%$ sulfanilamide, $0.1 \%$ naphthylethylene-diamine dihydrochloride in $2 \%$ phosphoric acid) at room temperature. After 15 min incubation, the absorbance was determined at $560 \mathrm{~nm}$. Nitrite content was determined by using sodium nitrite as standard.

\section{2. 4. ICAM-1 Assay}

Inhibition of the expression of the adhesion molecule ICAM-1 was conducted as described in our previous publication. ${ }^{45}$ Confluent grown HMEC-1 cells were pretreated either with test substances $(100 \mu \mathrm{M})$, parthenolide (Calbiochem, purity $\geq 97 \%, 5 \mu \mathrm{M}$, positive control) or culture medium as negative control in 24 -well plates. 30 minutes later, $10 \mathrm{ng} / \mathrm{mL}$ TNF- $\alpha$ (Sigma-Aldrich) were added to stimulate ICAM-1-expression. After $24 \mathrm{~h}$ of incubation (New Brunswick Scientific, $37{ }^{\circ} \mathrm{C}, 5 \% \mathrm{CO}_{2}$ ), cells were washed with PBS, removed from the plate with trypsin/EDTA and fixed with formalin. After incubating with a FITC-labelled mouse antibody against ICAM-1 (Biozol) for $20 \mathrm{~min}$, the fluorescence intensity was measured by FACS analysis 
(Becton Dickinson Facscalibur ${ }^{\mathrm{TM}}$ ). ICAM-1-expression of cells treated with TNF- $\alpha$ only was set as $100 \%$.

\section{2. 5. Antimicrobial Activity}

The in vitro antimicrobial activity of samples 1-3 was tested against a panel of laboratory control strains belonging to American Type Culture Collection Maryland, USA. Antimicrobial activity was evaluated against two Gram-positive bacteria (Bacillus subtilis ATCC 6633 and Staphylococcus aureus ATCC 6538), three Gram-negative bacteria (Escherichia coli ATCC 8739, Pseudomonas aeruginosa ATCC 9027 and Salmonella typhimurium ATCC 14028).

The minimal inhibitory concentration (MIC) of samples, against tested bacteria was determined by using a broth microdilution method. ${ }^{46}$ After overnight cultivation, microbial suspensions were made in Mueller Hinton broth and their turbidity was standardized to $0.5 \mathrm{McFar}-$ land. Dimethyl sulphoxide (10\%, v/v aqueous solution) was used to dissolve and to dilute the samples. A serial double dilution of the samples was prepared in 96 well microtiter plates, using the method of Sarker et al. ${ }^{47}$ The lowest concentration of the sample that inhibited visible growth was taken as the MIC value. One row was used as a positive control and contained a broad-spectrum antibiotic (doxycycline in a serial dilution of $200-0.05 \mu \mathrm{g} / \mathrm{mL}$ ) to determine the sensitivity of Gram-negative and Gram-positive bacteria while the other row contained the solvent as negative control. Tests were carried out in triplicate.

\section{2. 6. Statistical Analysis of the Biological Data}

Results are presented as mean \pm SD and refer to untreated control cells, which were set as $100 \%$ values. If not mentioned otherwise, experiments were carried out with three parallels and repeated independently at least three times. Statistical analysis was performed using GraphPad Prism 4 Software. Data were subjected to oneway ANOVA followed by Dunnett's multiple comparison test. Levels of significance: $p \leq 0.05(*), p \leq 0.01(* *)$.

\section{Results and Discussion}

\section{1. Synthesis and Structure}

The synthesis of $N$-( $\alpha$-bromoacyl)- $\alpha$-amino esters 1-3, containing valine as the $N$-terminal amino acid, is illustrated in Scheme 1. Briefly, $(R, S)$-2-bromo-3-methylbutanoyl chloride reacted with appropriate hydrochlorides of amino acid esters in dichloromethane at $0{ }^{\circ} \mathrm{C}$. Methyl ester of D-norvaline was applied in order to obtain a dipeptide derivative with two aliphatic side chains, whereas the aromatic fragments were introduced by reacting with methyl esters of L-phenylglycine and L-phenylalanine. Excess of triethylamine was used to release the free amino acid esters in the reaction mixture as well as to ensure deprotonation of the amino group by capturing the hydrogen chloride formed during the reaction. The corresponding $N$-( $\alpha$-bromo methylbutanoyl)- $\alpha$-amino esters 1-3 were obtained in moderate yields (61-67\%), isolated and purified by multiple recrystallization. To the best of our knowledge this is the first report on the synthesis of compounds 1-3.

The structures of $\mathbf{1}-\mathbf{3}$ were confirmed by IR, ${ }^{1} \mathrm{H}$ and ${ }^{13} \mathrm{C}$ NMR spectral data. The formation of the amide bond in 1-3 gives rise of several characteristic IR bands in the solid state IR spectrum: broad bands for the $\mathrm{N}-\mathrm{H}$ stretching vibration of the hydrogen bonded amide groups in the region $3340-3290 \mathrm{~cm}^{-1}$; very intense bands for the corresponding amide $\mathrm{C}=\mathrm{O}$ stretching vibration (Amide I) at $1653-1655 \mathrm{~cm}^{-1}$; and strong bands for the $\mathrm{N}-\mathrm{H}$ deformation vibration (Amide II) between 1554 and $1527 \mathrm{~cm}^{-1}$. The ester groups are characterized by very strong bands in the region $1744-1735 \mathrm{~cm}^{-1}$ for the carbonyl stretching vibrations. The bands for the $\mathrm{C}-\mathrm{H}$ vibrations of the aliphatic and phenyl fragments appear in their usual ranges.

The structures of the studied compounds 1-3 were confirmed with the help of 1D and 2D NMR spectra. The ${ }^{1} \mathrm{H}$ and ${ }^{13} \mathrm{C}$ spectra indicated the presence of a mixture of two diastereoisomers for all compounds. Having in mind the starting $(R, S)$ stereoconfiguration of 2-bromo-3methylbutanoyl chloride, C6 in the $N$-( $\alpha$-bromoacyl)- $\alpha$ amino esters is also expected to be $(R, S)$. The mechanism of the amide group formation does not involve conversion of the stereo configuration of the amino acid residues, therefore $\mathrm{C} 3$ is expected to remain $(S)$ or $(R)$ as initially present in the amino acid ester.

Single crystals of $\mathbf{1}$ and $\mathbf{2}$ were obtained by slow evaporation at room temperature, from a mixture of methanol/water. Both compounds crystallize in the noncentrosymmetric orthorhombic group $P 22_{l} 2_{l}$ (SG 19) with one molecule per asymmetric unit (Table 1). The ORTEP plot with the atomic numbering system of $\mathbf{1}$ and $\mathbf{2}$ is shown in Fig. 2 and selected bond distances and bond angles are listed in the Supplementary Material. Compounds 1 and 2 possess identical core atoms (1 through 6) and identical $\mathrm{R}^{2}$ substituents (Scheme 1), $\mathrm{R}^{1}$ substituents being the major difference. In addition, the unit cell parameters of $\mathbf{1}$ and $\mathbf{2}$ are nearly identical with $c$ value being a little bit higher for $\mathbf{2}$. Thus, it is not surprising that the major structural features of $\mathbf{1}$ and $\mathbf{2}$ are comparable: similar bond lengths and angles (see Supplementary Material). The X-ray single crystal analysis showed that both compounds crystallized as diastereoisomeric mixtures with $(R, S)$ configuration at $\mathrm{C} 6$. The initial stereo configuration of $\mathrm{C} 3$ in $\mathbf{1}$ and $\mathbf{2}$ is retained. The overlay of the molecules present in the asymmetric unit of $\mathbf{1}$ and $\mathbf{2}$ (Fig. 3) further supports the isotypical crystallization character of $\mathbf{1}$ and 2. Moreover, an identical disorder over two positions of the bromomethylpropyl moiety is observed in the structu- 
Table 1. Important crystallographic and refinement details for $\mathbf{1}$ and $\mathbf{2 .}$

\begin{tabular}{|c|c|c|}
\hline Compound & 1 & 2 \\
\hline Chemical formula & $\mathrm{C}_{11} \mathrm{H}_{18} \mathrm{BrNO}_{3}$ & $\mathrm{C}_{14} \mathrm{H}_{16} \mathrm{BrNO}_{3}$ \\
\hline $\begin{array}{l}M W \\
\text { Crystal system, SG }\end{array}$ & $\begin{array}{l}292.17 \\
\text { Orthorhombic } P 2.2 .2\end{array}$ & $\begin{array}{l}326.19 \\
\text { Orthorhombic } P 2.2 .2\end{array}$ \\
\hline$a, \AA$ & $\begin{array}{c}\text { Orthorhombic, } P 2_{1} 2_{1} 2_{1} \\
4.8184(4)\end{array}$ & $\begin{array}{l}\text { Orthornombic, } P L_{1} L_{1} 2_{1} \\
4.8969(4)\end{array}$ \\
\hline$b, \AA$ & $14.9219(12)$ & $14.6562(11)$ \\
\hline$c, \AA$ & $20.4448(16)$ & $21.8615(17)$ \\
\hline$V, \AA^{3}$ & $1470.0(2)$ & $1569.0(2)$ \\
\hline$Z$ & 4 & 4 \\
\hline$F_{000}$ & 600 & 664 \\
\hline$D_{\mathrm{x}} \mathrm{Mg} \mathrm{m}^{-3}$ & 1.320 & 1.381 \\
\hline$\mu, \mathrm{mm}^{-1}$ & 3.78 & 3.61 \\
\hline$T, \mathrm{~K}$ & 290 & 290 \\
\hline $\begin{array}{l}\text { Measured reflections } \\
\text { / reflections with } I>2 \sigma(I)\end{array}$ & $6090 / 1740$ & $5032 / 1756$ \\
\hline Independent reflections & 2738 & 2421 \\
\hline Parameters & 172 & 209 \\
\hline$R_{\text {int }}$ & 0.031 & 0.035 \\
\hline$R\left[F^{2}>2 \sigma\left(F^{2}\right)\right]$ & 0.087 & 0.087 \\
\hline$w R\left(F^{2}\right)$ & 0.321 & 0.272 \\
\hline GOF & 1.05 & 1.05 \\
\hline
\end{tabular}

a)
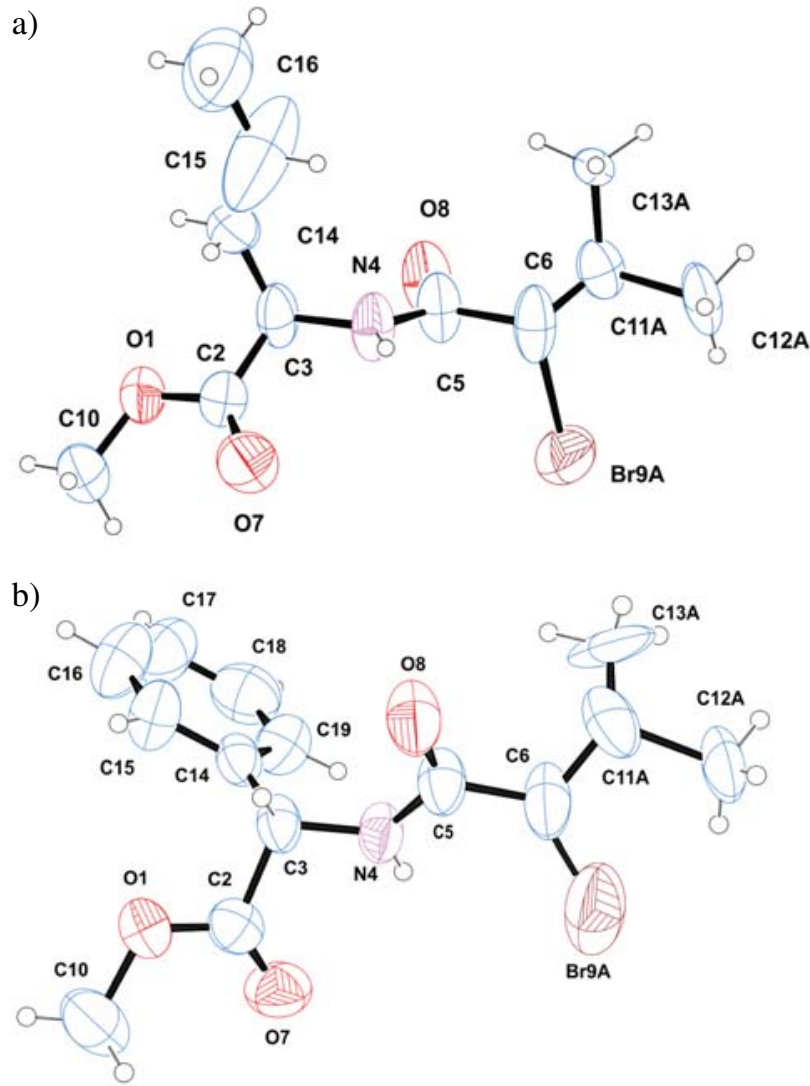

Figure 2. ORTEP view of compounds $\mathbf{1}$ (a) and $\mathbf{2}$ (b) with the atomic numbering scheme; ellipsoids are drawn at $40 \%$ probability, hydrogen atoms are shown as small spheres of arbitrary radii. Only the principal disorder component $(\mathrm{C} 11 \mathrm{~A}, \mathrm{C} 12 \mathrm{~A}, \mathrm{C} 13 \mathrm{~A}, \mathrm{Br} 9 \mathrm{~A})$ is represented. a)
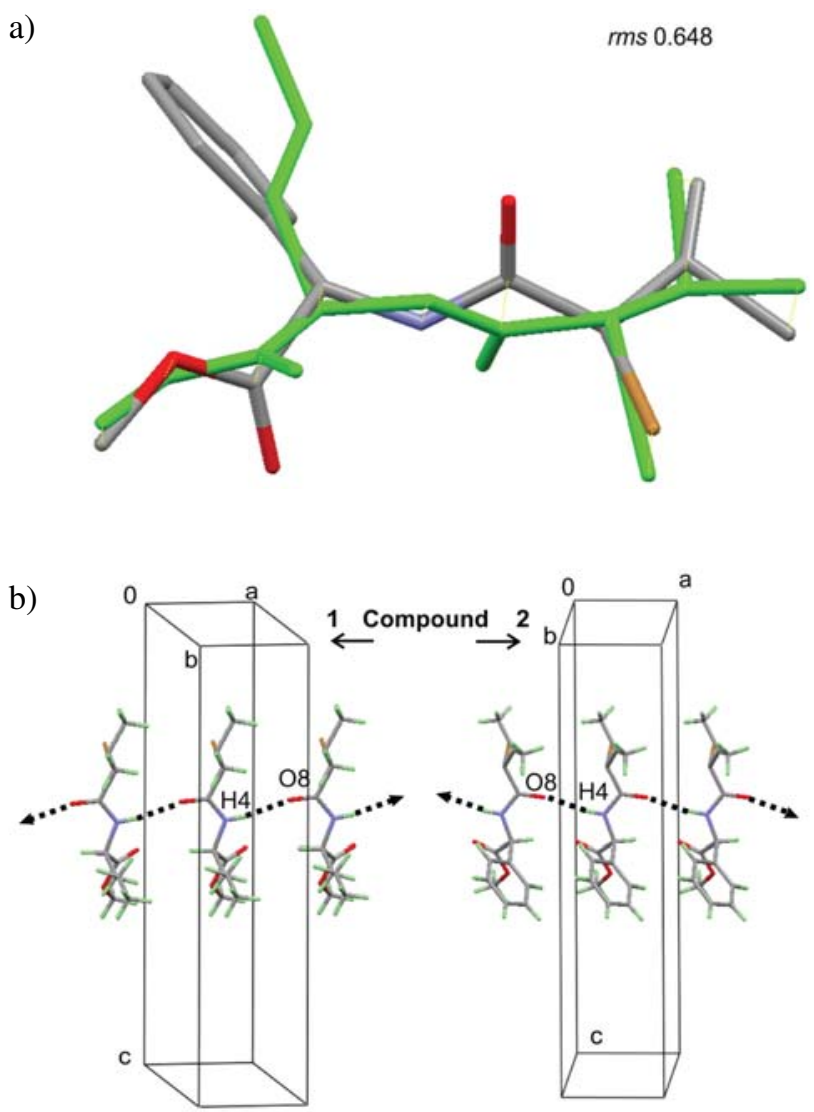

Figure 3. (a) Overlay of the core atoms of $\mathbf{1}$ (in green) and 2; the phenyl and propyl moieties ( $\mathrm{R}^{1}$ substituent, Scheme 1$)$ are not used in the overlay. The rms deviation between the atomic coordinate is $0.648 \AA$ and (b) Hydrogen bonding interaction in 1 and 2 . 
res of $\mathbf{1}$ and $\mathbf{2}$ (the principal component occupancy being $55 \%$ in both crystal structures). Finally, both structures are stabilized through identical hydrogen bonding interaction (N4-H4O8) building straight $\mathrm{C}^{1}{ }_{1}(4)$ chains along $a$ (Fig. 3b).

\section{2. Pharmacology}

\section{2. 1. Cytotoxicity}

The influence of compounds $\mathbf{1}-\mathbf{3}$ on the viability of HeLa and RAW264.7 cells was tested by MTT assays (Fig. 4). Only compounds $\mathbf{1}$ and $\mathbf{3}$ showed significant toxicity on HeLa cells in the highest concentration tested (100 $\mu \mathrm{M})$. Compound 2 showed no cytotoxic effects on HeLa cells at any used concentration (Fig. 4A). Viability of RAW264.7 macrophage cells was not affected by compound $\mathbf{1}$. Compound $\mathbf{2}$ significantly decreased viability at $100 \mu \mathrm{M}$ about $23 \%$ and compound $\mathbf{3}$ showed some toxicity at the highest concentration tested.

\section{2. 2. Anti-inflammatory Activity}

Nitrite accumulation in the culture medium is an indicator of NO synthesis, which is an important mediator in the inflammation process. In this set of experiments we found that exposure of RAW264.7 cells to increasing concentration of 1-3 was not able to induce a statistically significant decrease of nitrite concentration (Fig. 5). Only treatment with $100 \mu \mathrm{M}$ of compound 2 resulted in a reduced nitrite accumulation. However, this reduction is only due to the reduced cell number, caused by cytotoxic effects that were already observed in the MTT viability assay (Fig. 4).

The anti-inflammatory activity of $\mathbf{1}-\mathbf{3}$ was also measured in an in vitro ICAM-1 assay. None of the tested

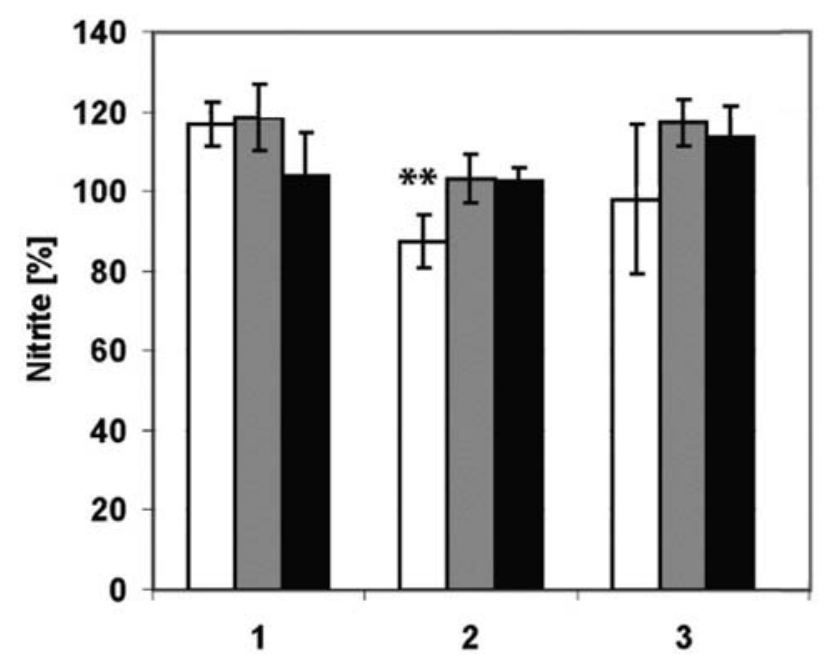

Figure 5. Influence of compounds 1-3 on nitrite accumulation in culture medium. Substances were tested at $1 \mu \mathrm{M}$ (dark grey bars), $10 \mu \mathrm{M}$ (light grey bars) and $100 \mu \mathrm{M}$ (white bars). Data is presented as mean percentage $\pm \mathrm{SD}$ in comparison to control cells. $n=9$ from three independent experiments.

compounds was able to reduce the TNF- $\alpha$ induced ICAM-1 expression in HMEC-1 cells at a concentration of $100 \mu \mathrm{M}$ (data not shown).

\section{2. 3. Antibacterial Activity}

According to the literature data ${ }^{48}$ a compound is considered as weak antimicrobial agent when its MIC value is above $1.50 \mathrm{mg} / \mathrm{mL}$. Therefore, we decided to examine compounds $\mathbf{1}-\mathbf{3}$ as potential antimicrobial agents, starting with a concentration of $2 \mathrm{mg} / \mathrm{mL}$. The compound $\mathbf{1}$ was tested with initial $2 \mathrm{mg} / \mathrm{mL}$, while the solubility of compounds $\mathbf{2}$ and $\mathbf{3}$ in 10\% dimethyl sulphoxide was limi-

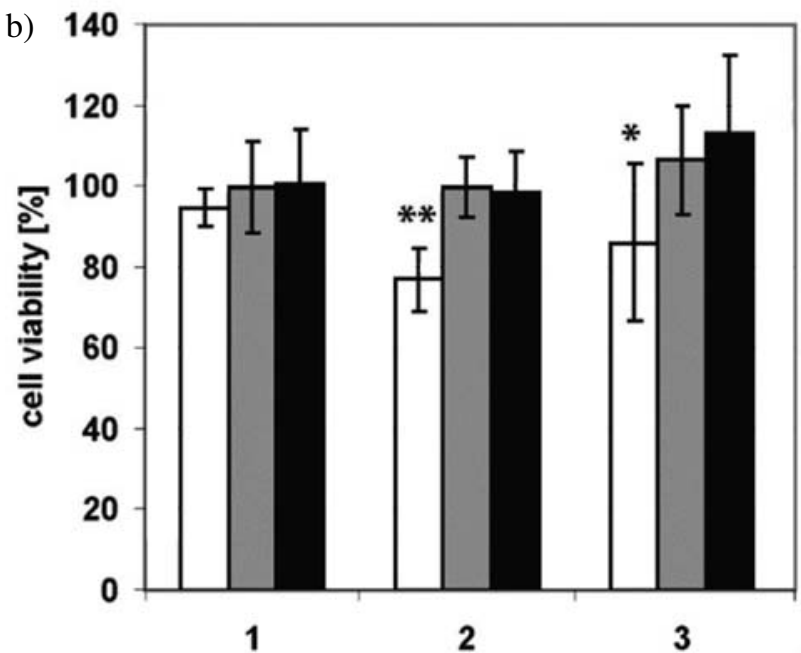

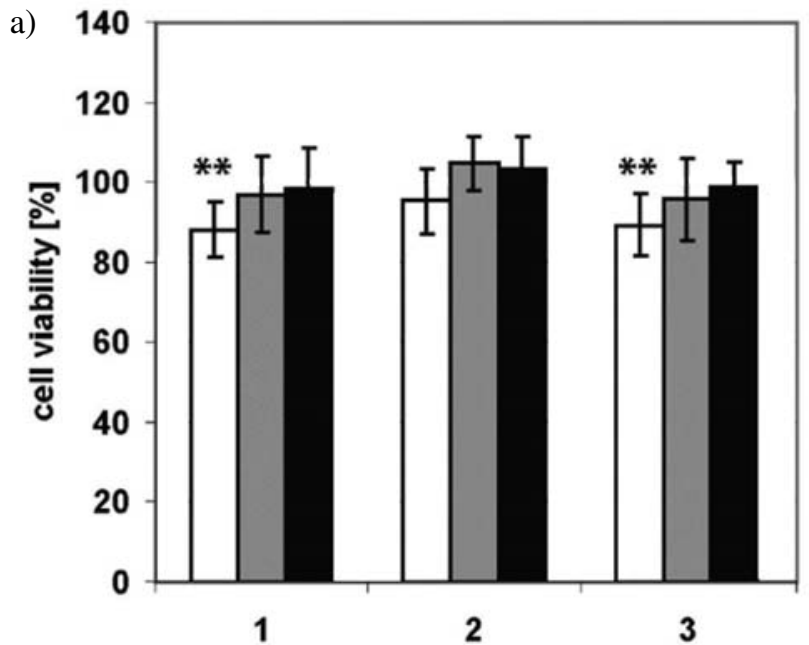

Figure 4. Influence of compounds 1-3 on the viability of (A) HeLa and (B) RAW264.7 cells after 24 h incubation. Substances were tested at $1 \mu$ M (dark grey bars), $10 \mu \mathrm{M}$ (light grey bars) and $100 \mu \mathrm{M}$ (white bars). Data is presented as mean percentage \pm SD in comparison to control cells. $n=9$ from three independent experiments. 
ted by the presence of phenyl groups in their structures, so the initial concentration for them was $1 \mathrm{mg} / \mathrm{mL}$. Compounds 1-3 showed no antibacterial activity in tested concentrations.

The results of our recent study of antibacterial activity of two cyclodidepsipeptides, 3,6-di(propan-2-yl)-4methyl-morpholine-2,5-dione and 3-(2-methylpropyl)-6(propan-2-yl)-4-methyl-morpholine-2,5-dione, indicated that MIC values against tested strains ranged between 2 and $25 \mathrm{mg} / \mathrm{mL}^{20}$ The 6-(propan-2-yl)-3-methyl-morpholine-2,5-dione showed antimicrobial activity against four of five tested bacterial strains, being the most effective against Escherichia coli. ${ }^{22}$ The cyclic didepsipeptide structure can be important for the antibacterial activity.

\section{3. Physico-chemical Properties and in silico Toxicological Study of Studied Compounds}

In view of future medical application, estimation of molecular physico-chemical properties such as lipophili- city, molecular size, flexibility and presence of hydrogen donors and acceptors is useful and considerably facilitates the development of new drug analogues with higher water-solubility at physiological $\mathrm{pH}$ and improved membrane permeability.

In order to estimate the potential of 1-3 for incorporation in prodrugs of acyclovir, their physico-chemical properties were calculated using Molinspiration tool, along with the properties of the hypothetical products of their coupling to acyclovir 4-6 (structures in Fig. 6). The results are summarized in Table 2. For comparison, the corresponding values of acyclovir (ACV) and two prodrugs of acyclovir (Val-ACV and Val-Val-ACV) were also calculated and included in Table 2.

The $\mathrm{m}_{\mathrm{i}} \log \mathrm{P}$ values of $\mathbf{1 - 3}$ increase with increasing the size of the alkyl chains present in the amino acid residues, while the topological polar surface area (TPSA) is not changing. TPSA is a sum of the surface areas occupied by the oxygen and nitrogen atoms and the hydrogens attached to them. It represents the hydrogen bonding capacity of the molecules. As could be seen in Table 1, the<smiles>[R]C(Br)C(=O)NC([R])C(=O)OCCOCn1cnc2c(=O)[nH]c(N)nc21</smiles>

Figure 6. Hypothetical products of the coupling of 1-3 to acyclovir.

Table 2. Calculated physico-chemical properties of compounds 1-6.

\begin{tabular}{|c|c|c|c|c|c|c|c|c|}
\hline Compd. No. & $\mathrm{m}_{\mathrm{i}} \log \mathrm{P}^{\mathrm{a}}$ & TPSA $^{b}$ & $\mathbf{N}_{\text {atoms }}{ }^{\mathbf{c}}$ & MW $^{d}$ & $\mathbf{N}_{\text {ON }}{ }^{\mathrm{e}}$ & $\mathbf{N}_{\text {OHNH }}{ }^{\mathbf{f}}$ & $\mathbf{N}_{\text {rotb. }}{ }^{\mathrm{g}}$ & Vol $^{\text {h }}$ \\
\hline$\overline{1}$ & 1.80 & 55 & 14 & 266 & 4 & 1 & 6 & 206 \\
\hline 2 & 1.96 & 55 & 17 & 300 & 4 & 1 & 5 & 228 \\
\hline 3 & 2.17 & 55 & 18 & 314 & 4 & 1 & 6 & 244 \\
\hline 4 & 1.16 & 154 & 30 & 487 & 11 & 4 & 12 & 390 \\
\hline 5 & 1.32 & 154 & 33 & 521 & 11 & 4 & 11 & 411 \\
\hline 6 & 1.52 & 154 & 34 & 535 & 11 & 4 & 12 & 428 \\
\hline Val-Val-ACV & -1.01 & 180 & 30 & 423 & 12 & 6 & 11 & 383 \\
\hline Val-ACV & -1.22 & 151 & 23 & 324 & 10 & 5 & 8 & 285 \\
\hline $\mathrm{ACV}$ & -1.61 & 119 & 16 & 225 & 8 & 4 & 4 & 187 \\
\hline
\end{tabular}

${ }^{\mathrm{a}}$ octanol-water partition coefficient, calculated by the methodology developed by Molinspiration; ${ }^{\mathrm{b}}$ polar surface area; ${ }^{\mathrm{c}}$ number of nonhydrogen atoms; ${ }^{\mathrm{d}}$ molecular weight; ${ }^{\mathrm{e}}$ number of hydrogen-bond acceptors (O and $\mathrm{N}$ atoms $) ;{ }^{\mathrm{f}}$ number of hydrogen-bond donors $\left(\mathrm{OH}\right.$ and $\mathrm{NH}$ groups); ${ }^{\mathrm{g}}$ number of rotatable bonds; ${ }^{\mathrm{h}}$ molecular volume 
hypothetical products of the coupling to acyclovir also show increasing lipophilicity with constant TPSA. The ACV derivatives 4-6 having larger alkyl chains are more lipophilic than ACV, Val-ACV and Val-Val-ACV. The therapeutic effect of $\mathbf{A C V}$ is limited due to its poor solubility in water ${ }^{49}$ and low oral, intravenous and corneal bioavailabilities. ${ }^{50-52}$ Val-ACV and Val-Val-ACV show improved antiviral efficacy against herpes infections and significantly lower cytotoxicity. ${ }^{53,54}$ The advantage of the amino acid and dipeptide prodrugs of $\mathbf{A C V}$ is attributed to their better water solubility at physiological $\mathrm{pH}$ and their enhanced transepithelial and transcorneal permeabilities mediated by hPEPT1 oligopeptide transporters ${ }^{55} \mathrm{~m}_{\mathrm{i}} \log \mathrm{P}$ values of ACV derivatives 4-6 suggest that incorporation of $n$-alkyl and aryl side chains in the dipeptide carrier allows gradual adjustment of the lipophilicity to the desired level.

Hydrogen bonding capacity of 1-3 was assessed also by the number of H-bond donors and acceptors. Compounds 1-3 possess four $\mathrm{H}$-bond acceptor sites and one $\mathrm{H}$-bond donor site. The number of $\mathrm{H}$-bond acceptors in the ACV derivatives 4-6 is more than 10-the limit recommended by the $»$ Rule of 5 « of Lipinski. ${ }^{56}$ Another indicator for the oral bioavailability as well as the efficient bonding of receptors and channels is the conformational flexibility of the molecules described by the number of rotatable bonds. ${ }^{57}$ Sufficient oral bioavailability is expected for molecules with 10 rotatable bonds or fewer. The ACV derivatives 6-8 show slightly higher number of rotatable bonds (11-12). However, this should not hinder the possible application of these compounds as ACV prodrugs as it is known that substrates for biological transporters are exceptions to the »Rule of $5 \ll .{ }^{55}$ ValVal-ACV itself illustrates this exception with $12 \mathrm{H}$-bond acceptor sites, $6 \mathrm{H}$-bond donor sites and 11 rotatable bonds.

Summarizing the physico-chemical properties of cyclodidepsipeptides in our recent review, ${ }^{58}$ we concluded that they obey the »Rule of 5 « and meet all criteria for good solubility and permeability in such a way that they allow further structural modifications for achieving desired pharmacological properties by introduction of particularly interesting structural motives. Based on the physico-chemical properties of $\mathbf{1}-\mathbf{3}$, and their hypothetical ACV derivatives 4-6, it could be suggested that the design of dipeptide carriers with aliphatic (Nva) and aromatic (Phg and Phe) side chains represents a promising strategy for adjustment of the lipophilicity, prodrug stability and pharmacological activity of dipeptide prodrugs of acyclovir, and also of other drugs containing hydroxy, thiol and amino groups. The potential of $\mathbf{1}-\mathbf{3}$ for incorporation in prodrugs is supported also by the low level of cytotoxicity revealed by our studies on HeLa and RAW264.7 cells. Having that prerequisite, the modification of the drug properties will be provided without leading to undesired cytotoxicity.
In order to obtain a complete picture of the toxicity of the three studied $N$-( $\alpha$-bromoacyl)- $\alpha$-amino esters containing valyl moiety, we calculated toxicity properties of compounds 1-3 using the OSIRIS Property Explorer. ${ }^{37}$ The data thus obtained indicate that structures of compounds 1-3 are supposed to be non-mutagenic, non-tumorigenic, non-irritating and with no reproductive effects.

\section{Conclusions}

Three novel $N$-( $\alpha$-haloacyl)- $\alpha$-amino esters: methyl 2-(2-bromo-3-methylbutanamido)pentanoate (1), methyl 2-(2-bromo-3-methylbutanamido)-2-phenylacetate (2) and methyl 2-(2-bromo-3-methylbutanamido)-3-phenylpropanoate (3) were synthesized. Single crystals of $\mathbf{1}$ and 2 were elucidated by X-ray diffraction.

Only at the highest concentration tested $(100 \mu \mathrm{M})$ the studied noncyclic dipeptides 1-3 showed some signs of cytotoxicity on HeLa cells and/or RAW264.7 cells. However, the compounds showed neither influence on LPSinduced NO-formation nor on ICAM-1 expression. Compounds 1-3 showed no antibacterial activity in tested concentrations. The results obtained in this study are in accordance with suggestion given in previous reports ${ }^{59,60}$ and review ${ }^{61}$ on cyclodepsipeptides that the ring form is required for biological activity.

The low level of cytotoxicity of $\mathbf{1 - 3}$ established by our studies on HeLa and RAW264.7 cells, and in silico toxicological study using the OSIRIS Property Explorer $^{37}$ as well as the absence of antibacterial and anti-inflammatory activity, might be a beneficial prerequisite for their incorporation in prodrugs which would allow modification of the drug properties without inducing undesired cytotoxicity and antimicrobial activity. Aliphatic and aromatic side chains incorporated in the dipeptide carrier would allow a gradual adjustment of the lipophilicity, prodrug stability and pharmacological activity of dipeptide prodrugs of acyclovir, and also of other drugs containing hydroxy, thiol and amino groups.

\section{Acknowledgments}

The authors show gratitude to National Science Fund of Bulgaria (young researchers' project DMU03/66, grants DRNF02/1 and DRNF02/13) and Ministry of Education and Science of the Republic of Serbia (grant no. 172044) for the financial support of this work. We also wish to thank the Alexander von Humboldt Foundation (Bonn, Germany) for their support through a fellowship to A. Smelcerovic. We thank Dr. E. Ades, F. J. Candal (CDC, Atlanta, GA, USA) and Dr. T. Lawley (Emory University, Atlanta, GA, USA) for providing HMEC-1. Furthermore, we thank Prof. Jörg Heilmann (Pharmaceutical Biology, University of Regensburg) for stimulating discussion. 


\section{References}

1. A. P. Bras, D. S. Sitar, F. Y. Aoki, Can. J. Clin. Pharmacol. 2001, 8, 207-211. http://dx.doi.org/10.1034/j.1600-0773.2002.900602.x

2. K. Linden, X. X. Zhou, L. Stable, Pharmacol. Toxicol. 2002, 90, 297-302.

3. S. Tolle-Sander, K. A. Lentz, D. Y. Maeda, A. Coop, J. E. Polli, Mol. Pharm. 2004, 1, 40-48. http://dx.doi.org/10.1021/mp034010t

4. C. Santos, R. Capela, C. Pereira, C. Pannecouque, E. de Clercq, R. Moreira, P. Gomes, Eur. J. Med. Chem. 2009, 44, 2339-2346. http://dx.doi.org/10.1016/j.ejmech.2008.08.009

5. M. Barot, M. Bagui, M. R. Gokulgandhi, A. K. Mitra, Med. Chem. 2012, 8, 753-768. http://dx.doi.org/10.2174/157340612801216283

6. C. Santos, J. Morais, L. Gouveia, E. de Clercq, C. Pannecouque, C. U. Nielsen, B. Steffansen, R. Moreira, P. Gomes, ChemMedChem 2008, 3, 970-978. http://dx.doi.org/10.1002/cmdc.200800012

7. Y. Tsume, J. M. Hilfinger, G. L. Amidon, Pharm. Res. 2011, $28,2575-2588$. http://dx.doi.org/10.1007/s11095-011-0485-7

8. L. Zhang, L. Zhang, T. Luo, J. Zhou, L. Sun, Y. Xu, ACS Comb. Sci. 2012, 14, 108-114. http://dx.doi.org/10.1021/co200141b

9. Y. Tsume, G. L. Amidon, J. Pharm. Pharm. Sci. 2012, 15, 433-446.

10. C. Santos, M. L. Mateus, A. P. dos Santos, R. Moreira, E. de Oliveira, P. Gomes, Bioorg. Med. Chem. Lett. 2005, 15, 1595-1598. http://dx.doi.org/10.1016/j.bmcl.2005.01.065

11. D. H. Omkvist, D. J. Trangbæk, J. Mildon, J. S. Paine, B. Brodin, M. Begtrup, C. U. Nielsen, Eur. J. Pharm. Biopharm. 2011, 77, 327-331. http://dx.doi.org/10.1016/j.ejpb.2010.12.009

12. A. Diez-Torrubia, S. Cabrera, A. M. Lambeir, J. Balzarini, M. J. Camarasa, S. Velázquez, ChemMedChem 2012, 7, 618-628. http://dx.doi.org/10.1002/cmdc.201100504

13. M. C. Chung, M. F. Gonçalves, W. Colli, E. I. Ferreira, M. T. Miranda, J. Pharm. Sci. 1997, 86, 1127-1131. http://dx.doi.org/10.1021/js970006v

14. N. Vale, F. Nogueira, V. E. do Rosário, P. Gomes, R. Moreira, Eur. J. Med. Chem. 2009, 44, 2506-2516. http://dx.doi.org/10.1016/j.ejmech.2009.01.018

15. G. H. G. Trossini, C. M. Chin, C. M. de Souza Menezes, E. I. Ferreira, Lett. Drug. Des. Discov. 2010, 7, 528-533. http://dx.doi.org/10.2174/157018010791526287

16. H. J. Kim, Y. Kim, E. T. Choi, M. H. Lee, E. S. No, Y. S. Park, Tetrahedron 2006, 62, 6303-6311. http://dx.doi.org/10.1016/j.tet.2006.04.045

17. Y. S. Park, Tetrahedron: Asymmetry 2009, 20, 2421-2427. http://dx.doi.org/10.1016/j.tetasy.2009.10.014

18. J. Nam, J.-y. Chang, E.-k. Shin, H. J. Kim, Y. Kim, S. Jang, Y. S. Park, Tetrahedron 2004, 60, 6311-6318. http://dx.doi.org/10.1016/j.tet.2004.05.094
19. E.-k. Shin, J.-y. Chang, H. J. Kim, Y. Kim, Y. S. Park, B. Kor. Chem. Soc. 2006, 27, 447-449.

20. V. Pavlovic, A. Djordjevic, E. Cherneva, D. Yancheva, A. Smelcerovic, Food Chem. Toxicol. 2012, 50, 761-766. http://dx.doi.org/10.1016/j.fct.2011.11.032

21. V. Pavlovic, E. Cherneva, D. Yancheva, A. Smelcerovic, Food Chem. Toxicol. 2012, 50, 3014-3018. http://dx.doi.org/10.1016/j.fct.2012.06.004

22. D. Yancheva, L. Daskalova, E. Cherneva, B. Mikhova, A. Djordjevic, Z. Smelcerovic, A. Smelcerovic, J. Mol. Struct. 2012, 1016, 147-154. http://dx.doi.org/10.1016/j.molstruc.2012.02.057

23. M. Iijima, T. Masuda, H. Nakamura, H. Naganawa, S. Kurasawa, Y. Okami, M. Ishizuka, T. Takeuchi, Y. Iitake, J. Antibiot. (Tokyo) 1992, 45, 1553-1556. http://dx.doi.org/10.7164/antibiotics.45.1553

24. A. Smelcerovic, M. Rangelov, Z. Smelcerovic, A. Veljkovic, E. Cherneva, D. Yancheva, G. M. Nikolic, Z. Petronijevic, G. Kocic, Food Chem. Toxicol. 2013, 55, 493-497. http://dx.doi.org/10.1016/j.fct.2013.01.052

25. K. Hasumi, C. Shinohara, T. Iwanaga, A. Endo, J. Antibiot. (Tokyo) 1993, 46, 1782-1787. http://dx.doi.org/10.7164/antibiotics.46.1782

26. A. Arcelli, D. Balducci, A. Grandi, G. Porzi, M. Sandri, S. Sandri, Monatsh. Chem. 2004, 135, 951-958. http://dx.doi.org/10.1007/s00706-004-0195-5

27. A. Arcelli, D. Balducci, A. Grandi, G. Porzi, M. Sandri, S. Sandri, Tetrahedron: Asymmetry 2005, 16, 1495-1501. http://dx.doi.org/10.1016/j.tetasy.2005.03.007

28. A. Arcelli, D. Balducci, S. F. E. Neto, G. Porzi, M. Sandri, Tetrahedron: Asymmetry 2007, 18, 562-568. http://dx.doi.org/10.1016/j.tetasy.2007.02.013

29. T. Kagamizono, E. Nishino, K. Matsumoto, A. Kawashima, M. Kishimoto, N. Sakai, B. M. He, Z. X. Chen, T. Adachi, S. Morimoto, K. Hanada, J. Antibiot. (Tokyo) 1995, 48, 14071412. http://dx.doi.org/10.7164/antibiotics.48.1407

30. A. Smelcerovic, D. Yancheva, E. Cherneva, Z. Petronijevic, M. Lamshoeft, D. Herebian, J. Mol. Struct. 2011, 985, 397402. http://dx.doi.org/10.1016/j.molstruc.2010.11.029

31. N. S. Abbas, E. A. Ahmed, Acta. Chim. Slov. 2014, 61, 835-843.

32. M. Saeidifar, H. Mansouri-Torshizi, Y. Palizdar, M. EslamiMoghaddam, A. Divsalar, A. A. Saboury, Acta. Chim. Slov. 2014, 61, 126-136.

33. R. M. Mohareb, N. S. Abbas, R. A. Ibrahim, Acta. Chim. Slov. 2013, 60, 583-594.

34. A. Abbas, M. M. Naseer, Acta. Chim. Slov. 2014, 61, 792802.

35. M. Jukič, A. Đorđević, J. Lazarević, M. Gobec, A. Šmelcerović, M. Anderluh, Mol. Divers. 2013, 17, 773-780. http://dx.doi.org/10.1007/s11030-013-9474-6

36. Molinspiration Cheminformatics, 2013 http://www.molinspiration.com; Molinspiration property engine v2013.09

37. OSIRIS Property Explorer, http://www.organic-chemistry. org/prog/peo/

38. J. G. Gleason, D. N. Harpp, Tetrahedron Lett. 1970, 39, 
3431-3434.

http://dx.doi.org/10.1016/S0040-4039(01)98495-3

39. Agilent, CrysAlis PRO, Agilent Technologies Ltd., Yarnton, England, 2010.

40. G. M. Sheldrick, Acta Crystallogr. A 2008, 64, 112-122. http://dx.doi.org/10.1107/S0108767307043930

41. W. C. Raschke, S. Baird, P. Ralph, I. Nakoinz, Cell 1978, 15, 261-267. http://dx.doi.org/10.1016/0092-8674(78)90101-0

42. E. W. Ades, F. J. Candal, R. A. Swerlick, V. G. George, S. Summers, D. C. Bosse, T. J. Lawle, J. Invest. Dermatol. 1992, 99, 683-690.

http://dx.doi.org/10.1111/1523-1747.ep12613748

43. T. Mosmann, J. Immunol. Methods 1983, 65, 55-63. http://dx.doi.org/10.1016/0022-1759(83)90303-4

44. B. Kraus, H. Wolff, E. F. Elstner, J. Heilmann, N-S. Arch. Pharmacol. 2010, 381, 541-553.

45. A. Freischmidt, G. Jürgenliemk, B. Kraus, S. N. Okpanyi, J. Müller, O. Kelber, D. Weiser, J. Heilmann, Phytomedicine 2012, 19, 245-252. http://dx.doi.org/10.1016/j.phymed.2011.08.065

46. National Committee for Clinical Laboratory Standards, Performance standards for antimicrobial susceptibility testing: eleventh informational supplement, M100-S11. National Committee for Clinical Laboratory Standard, Wayne, PA, USA, 2003.

47. S. A. Sarker, L. Nahar, Y. Kumarasamy, Methods 2007, 42, 321-324. http://dx.doi.org/10.1016/j.ymeth.2007.01.006

48. A. Sartoratto, A. L. M. Machado, C. Delarmelina, G. M. Figueira, M. C. T. Duarte, V. L. G. Rehder, Brazil. J. Microbiol. 2004, 35, 275-280.

49. L. Colla, E. De Clercq, R. Busson, H. Vanderhaeghe, J. Med. Chem. 1983, 26, 602-604. http://dx.doi.org/10.1021/jm00358a029

50. P. M. Hughes, R. Krishnamoorthy, A. K. Mitra, J. Ocul.
Pharmacol. 1993, 9, 287-297. http://dx.doi.org/10.1089/jop.1993.9.287

51. P. M. Hughes, A. K. Mitra, J. Ocul. Pharmacol. 1993, 9 , 299-309. http://dx.doi.org/10.1089/jop.1993.9.299

52. H. Gao, A. Mitra, Synth. Commun. 2001, 31, 1399-1419. http://dx.doi.org/10.1081/SCC-100104050

53. S. Weller, M. R. Blum, M. Doucette, T. Burnette, D. M. Cederberg, P. de Miranda, M. L. Smiley, Clin. Pharmacol. Ther. 1993, 54, 595-605. http://dx.doi.org/10.1038/clpt.1993.196

54. B. S. Anand, J. M. Hill, S. Dey, K. Maruyama, P. S. Bhattacharjee, M. E. Mylas, Y. E. Nashed, A. K. Mitra, Invest. Ophthalmol. Vis. Sci. 2003, 44, 2529-2534. http://dx.doi.org/10.1167/iovs.02-1251

55. B. S. Anand, S. Katragadda, A. K. Mitra, J. Pharmacol. Exp. Ther. 2004, 311, 659-667. http://dx.doi.org/10.1124/jpet.104.069997

56. C. A. Lipinski, F. Lombardo, B. W. Dominy, P. J. Feeney, Adv. Drug Deliver. Rev. 2012, 64, 4-17. http://dx.doi.org/10.1016/j.addr.2012.09.019

57. D. F. Veber, S. R. Johnson, H.-Y. Cheng, B. R. Smith, K. W. Ward, K. D. Kopple, J. Med. Chem. 2002, 45, 2615-2623. http://dx.doi.org/10.1021/jm020017n

58. A. Smelcerovic, V. Pavlovic, P. Dzodic, E. Cherneva, D. Yancheva, Amino Acids 2014, 46, 825-840. http://dx.doi.org/10.1007/s00726-014-1666-6

59. M. T. Hamann, C. S. Otto, P. J. Scheuer, D. C. Dunbar, J. Org. Chem. 1996, 61, 6594-6600. http://dx.doi.org/10.1021/jo960877+

60. M. Isaka, S. Palasarn, S. Lapanun, K. Sriklung, J. Nat. Prod. 2007, 70, 675-678. http://dx.doi.org/10.1021/np060602h

61. R. Lemmens-Gruber, M. R. Kamyar, R. Dornetshuber, Curr. Med. Chem. 2009, 16, 1122-1137. http://dx.doi.org/10.2174/092986709787581761

\section{Povzetek}

Pripravili smo tri nove $N$-( $\alpha$-bromoacil)- $\alpha$-amino estre: metil 2-(2-bromo-3-metilbutanamido)pentanoat (1), metil 2-(2bromo-3-metilbutanamido)-2-fenilacetat (2) in metil 2-(2-bromo-3-metilbutanamido)-3-fenilpropanoat (3). Objavljamo rezultate rentgenske difrakcije analize monokristalov spojin $\mathbf{1}$ in $\mathbf{2}$. Raziskali smo tudi citotoksičnost, anti-inflamatorno in antibakterijsko aktivnost spojin 1-3. Dodatno smo izračunali fizikalno-kemijske lastnosti teh spojin ter zanje izvedli in silico toksikološko študijo. Nizka raven citotoksičnosti in odsotnost antibakterijske in anti-inflamatorne aktivnosti za spojine 1-3 v okviru testiranih koncentracij bi lahko bila dobrodošla lasnost za njihovo morebitno vgrajevanje v prozdravila. 